\title{
The battle over the benefits: analysing two sport hunting policy arrangements in Uganda
}

\author{
Amos Ochieng, Ingrid J. Visseren-Hamakers and René Van Der Duim
}

\begin{abstract}
In 2001 sport hunting was reintroduced in Uganda around Lake Mburo National Park, and in 2008 at Kabwoya and Kaiso-Tonya Game Management Area, to derive economic benefits for communities and thus reduce human-wildlife conflict and change communities' attitudes towards wildlife. We used the policy arrangement approach to analyse and compare the development of the two sport hunting policy arrangements. Through interviews and document review we learned that the arrangement at Lake Mburo changed considerably over time, whereas that at Kabwoya remained relatively stable. The two policy arrangements started with small constellations of actors but turned out to be complex arenas, mainly involving disagreement regarding the benefits. Land ownership proved to be a crucial factor in explaining the differences between the arrangements. Our results also show that benefits do not change communities' attitudes towards conservation, thus questioning incentive-based policies for conservation. We argue for a careful analysis of the complex social, cultural and political contexts in which conservation and development policies are implemented, to better understand their outcomes.
\end{abstract}

Keywords Human-wildlife conflict, incentive-based approach, market-based conservation, policy arrangement approach, sport hunting, Uganda

\section{Introduction}

C onservation organizations in Africa have struggled to develop new, more participatory forms of wildlife conservation and management, recognizing that residents living adjacent to conservation areas suffer from crop loss and pasture depletion, competition for saltlicks and water between wildlife and cattle, and exposure to diseases carried by wildlife (Ochieng, 2011). This necessitates developing

\footnotetext{
Amos Ochieng (Corresponding author) Department of Forestry, Biodiversity and Tourism, Makerere University, Kampala, Uganda

E-mail aochiengd@gmail.com

Ingrid J. Visseren-Hamakers Department of Environmental Science and Policy, George Mason University, Fairfax, USA, and Forest and Nature Conservation Policy Group, Wageningen University and Research Centre, Wageningen, The Netherlands

RENÉ VAN DER DUim Cultural Geography Group, Wageningen University and Research Centre, Wageningen, The Netherlands

Received 4 February 2016. Revision requested 1 April 2016.

Accepted 3 August 2016. First published online 12 January 2017.
}

new policies to ensure that conservation links with and contributes to human welfare and development.

In terms of human development, advocates have implemented sport hunting as a market- and community-based approach (Hulme \& Murphree, 2001). Sport hunting involves hunters (often tourists) paying to chase and kill an animal for pleasure (Loveridge et al., 2006). It is practised in diverse forms in c. 23 African countries (Lewis \& Alpert, 1997; van der Duim et al., 2015), with $>18,500$ clients (Lindsey et al., 2007) generating revenue of c. USD 200 million annually (Booth, 2010).

The debate on sport hunting hinges on fundamental concerns (Hutton \& Leader-Williams, 2003; Yasuda, 2012). Proponents (e.g. Hutton \& Leader-Williams, 2003; Nelson et al., 2013) argue that people will actively support and practise conservation if they derive tangible benefits from wildlife. Critics argue that sport hunting causes stress and distress among animals, and can lead to extinction of species (Fischer et al., 2013). Büscher et al. (2012) and Fletcher (2010) contend that the neoliberal tendencies associated with sport hunting disenfranchise local residents and national governments, and hamper their participation and ability to derive benefits from conservation. Consequently, it is argued that the contributions of sport hunting benefits in southern and eastern Africa are insufficient to improve human welfare (Booth, 2010).

In Uganda, sport hunting started in the 19oos to meet the demands of the colonial administrators, and African kings and chiefs (Ayorekire et al., 2011), and rural communities also practised small-scale hunting for consumption. The practice was legalized in 1926 through the Game Ordinance (Ochieng et al., 2015). This regime of hunting lasted until 1979, when a ministerial ban was issued because of decreasing wildlife populations (Ayorekire et al., 2011). In 2001 the Uganda Wildlife Authority (the government authority responsible for managing wildlife in Uganda, hereafter the government) reintroduced sport hunting around Lake Mburo National Park (hereafter Lake Mburo; Fig. 1), and in 2008 at the Kabwoya and Kaiso-Tonya Game Management Area (hereafter Kabwoya; Fig. 2), with the formal goals of reducing poaching by local communities, providing incentives for local inhabitants to manage and protect wildlife, improving residents' attitudes towards wildlife, and providing lessons in developing guidelines and procedures for further implementation of sport hunting (UWA, 2001). The main species hunted include the zebra Equus burchelli boehmi, impala Aepyceros melampus, buffalo Syncerus caffer and bushbuck Tragelaphus scriptus, and to 

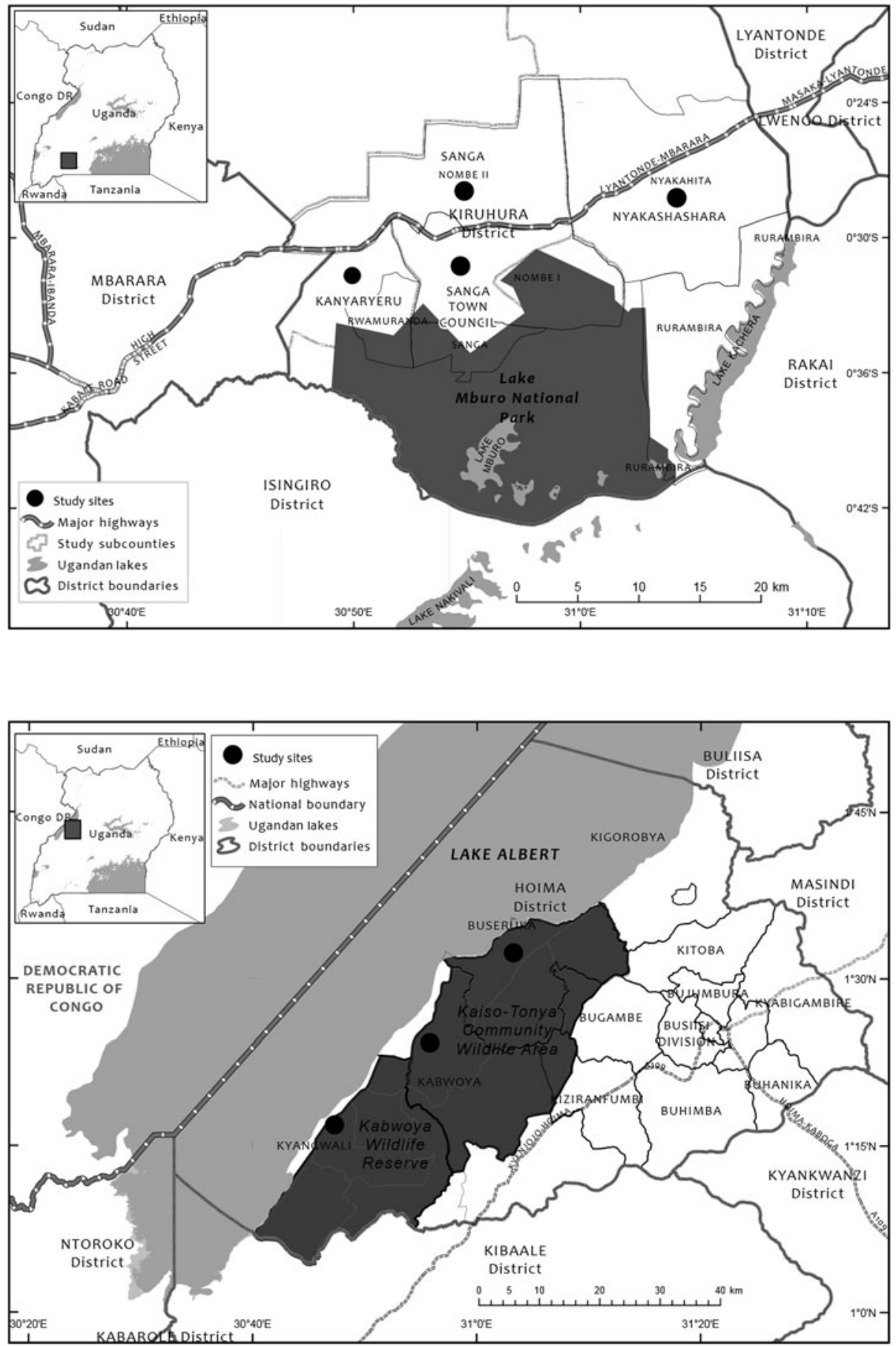

Fig. 1 Location of Lake Mburo National Park in Uganda.
FIG. 2 Location of Kabwoya Wildlife Reserve and Kaiso-Tonya Community Wildlife Area in Uganda. a lesser extent the hippopotamus Hippopotamus amphibius, leopard Panthera pardus and hyaena Crocuta crocuta (Ochieng et al., 2015). There is little in the conservation literature about hunting in Uganda, and this paper represents one of the first attempts to incorporate the issue of sport hunting in Uganda into international academic debates on hunting, development and conservation.

Our aim was to analyse the development of hunting policy in Uganda by focusing on two sites where sport hunting has been reintroduced. We employed the policy arrangement approach and the concept of congruence to answer the following research questions: (1) how did the sport hunting policy arrangements at Lake Mburo and Kabwoya evolve over time? and (2) what have been the driving forces for change?

\section{Theoretical framework}

We used the policy arrangement approach and the concept of congruence as a conceptual lens. Arts et al. (2006, p. 96) 
defined a policy arrangement as 'the temporary stabilization of the content and organization of a policy domain.' Policy arrangements stabilize only provisionally, as they are under constant pressure to accommodate new actors, rules, discourses and resources, or to (re)strategize to achieve goals (Van Gossum et al., 2011).

The policy arrangement approach was chosen because it has already been used successfully to study tourism and conservation policies in Africa (e.g. Ahebwa et al., 2012b; Lamers et al., 2014), and in many other policy fields, including forest and nature policy (van der Zouwen, 2006); it considers the organization of policies in terms of various actors and their resources, as well as the content in terms of rules and discourses; it can be used to understand the changes in the arrangement over time; and it builds on multi-actor network models (Rhodes, 1997), paying specific attention to the institutional contexts in which policy actors operate (Van Gossum et al., 2011).

The policy arrangement approach includes the following four dimensions: discourses, actors, rules and resources. Discourses are defined as narratives, sets of ideas, beliefs, concepts and stories used to give meaning to a phenomenon in a real setting, produced and reproduced through sets of practices (Hajer, 1995, p. 60). Actors are individuals and organizations involved in a particular policy domain (Arts et al., 2006). Actors with relatively similar opinions tendentiously converge into coalitions to oppose or support particular discourses or rules (van der Zouwen, 2006; Arts \& Buizer, 2009). Formal and informal rules consist of 'legislation', 'procedures' and 'political culture' (Wiering \& Arts, 2006) that 'guide and constrain the behaviour of actors' (Arts \& van Tatenhove, 2004, p. 342). Resources are assets such as authority, knowledge, finances, land and legitimacy, mobilized by policy actors (Wiering \& Arts, 2006), and are 'intrinsically linked to the concept of power' (Arts \& van Tatenhove, 2004, p. 343). Although power remains a contested concept (Kuindersma et al., 2012), we consider it to be a relational concept: the ability of actors to mobilize resources to achieve or influence outcomes within a policy domain (Giddens, 1984) through deliberation or even coercion. We used these four dimensions of the policy arrangement approach to analyse the change over time of the content and organization of the two sport hunting policy arrangements.

We also adopted the concept of congruence (Arts \& Goverde, 2006) to explain the changes in the arrangements over time. Although congruence can include both internal and external aspects, we focused on the internal congruence of the two arrangements, which we regard as the extent to which the policy dimensions (discourses, rules, actors and resources) are internally consistent. A key underlying assumption is that 'a certain level of congruence... is needed for any policy arrangement to perform. A failure to realize this certain level of congruence will imply a governance failure' (Arts \& Goverde, 2006, p. 80).

\section{Methods}

We focus on two cases (Yin, 2003): Lake Mburo and Kabwoya. Data sources include documents, observation notes and interviews. Interviews were conducted in two phases: October 2010-January 2011 and February-August 2014. For Lake Mburo, fieldwork covered four sub-counties (Kanyaryeru, Nyakashashara, Sanga and Sanga Town Board (Kiruhura district)), and for Kabwoya three sub-counties (Kabwoya, Buseruka, Kyangwali (Hoima district)). Most interviewees were selected using snowball sampling. NGO representatives and government officials were purposively selected (Kumar, 2012) because of their relative importance. Fifty-nine in-depth interviews were conducted: four ( $\mathrm{R} 1$, $\mathrm{R}, 2, \mathrm{R}_{3}, \mathrm{R}_{4} 6$ ) with national and local governmental conservation organizations, six $\left(\mathrm{R}_{39}-\mathrm{R}_{44}\right)$ with conservation NGOs, three (R47, R48, R52) with sport hunting companies, four (R16-R18, R55) with district local leaders, one ( $\mathrm{R}_{45}$ ) with a tourism association, nine ( $\left.\mathrm{R}_{19}-\mathrm{R}_{27}\right)$ with village leaders, 15 (R4-R15, R49, R58, R59) with the Uganda Wildlife Authority (Lake Mburo, Kabwoya), and 19 (R28-R38, R50 to $\mathrm{R} 57$ ) with local communities. Interviews were conducted in respondents' homes, offices and restaurants, lasted 20-90 minutes and were recorded. Three respondents agreed to be interviewed but declined to be recorded. Circa 20 informal conversations took place with various officials. Five respondents were interviewed twice. All recordings were transcribed. Interview transcripts, observation notes and documents were analysed thematically, implying 'a form of pattern recognition within the data, where emerging themes become the categories for analysis' (Fereday \& Muir-Cochrane, 2006, p. 4). Quotes from interviews are presented as evidence of respondents' perceptions of the policy arrangements, and are coded to anonymize respondents. The trustworthiness (cf. Decrop, 2004) of this research approach was established by the intense engagement of $\mathrm{AO}$ with the two cases, credibility was enhanced by systematic and transparent data analysis with tangible products (transcripts, codebook, coded transcripts), and joint analysis of the various data sources (interviews, documents and observation notes) provided validation by triangulation.

\section{Evolution of the sport hunting policy arrangements}

\section{Lake Mburo National Park}

The Lake Mburo sport hunting policy arrangement has been a dynamic arrangement, including four main periods, characterized by struggles over benefits.

2001-2003 In this period the sport hunting policy was developed and implemented. Actors were sensitized and rules were set, including about the distribution of benefits, 
based on the expectation that the policy would reduce human-wildlife conflict.

Sport hunting around Lake Mburo started with a small group of actors. The national government involved the local government at both district and sub-county levels (hereafter local government, responsible for enforcing government programmes, including wildlife management) and Community Protected Area institutions (hereafter institutions). These institutions were formed by the government in 1997 to harmonize community-protected area interactions in Uganda, including coordination of the disbursement of the $20 \%$ of tourism national park revenue fees that fund community-based development projects (Ahebwa et al., 2012a). At Lake Mburo the government implements two tourism models: traditional tourism, implemented within the park, with the community receiving $20 \%$ of the tourist entry fees, and sport hunting outside the park to raise funds to reduce poaching. The company Game Trails Uganda Limited was licensed by the government to organize sport hunting.

The government's policy mission was '...to conserve and sustainably manage wildlife...in partnership with neighbouring communities and other stakeholders for the benefit of Ugandans and the global community' (UWP, 2004, p. 2). Therefore, it was necessary for the government to find ways of incentivizing the communities to convince them to support sport hunting, and to reduce human-wildlife conflict. The communities include three groups of residents: rich and influential individuals who own large parcels of land, residents who own smaller parcels of land, and squatters (who don't own land).

To bring the communities on board, the government sponsored a familiarization trip to southern Africa and Tanzania to show institution members, the local government and some village opinion leaders how sport hunting was implemented there, and to learn how to run Community Wildlife Associations ( $\left.\mathrm{R}_{31}\right)$. These are community-based organizations that manage sport hunting benefits and implement community development projects. After the familiarization trip, meetings were held to sensitize the communities in Rurambiira parish (a parish is the lowest administrative unit in Uganda), where pilot hunting was to be implemented. Some respondents $\left(\mathrm{R}_{3}, \mathrm{R}_{4}, \mathrm{R}_{35}\right)$ revealed that the meetings had mixed results; residents approved of sport hunting and agreed to form the Rurambiira Wildlife Association, but also hoped that the policy implementation would ultimately reduce the presence of wildlife on their land (R6).

The meetings and discussions were followed by the formulation of rules, based on the Wildlife Use Rights Policy of 2000. The policy stipulates the categories under which individuals and organizations can own, use and benefit from wildlife. They include sport hunting, farming, ranching,
TABLE 1 The revenue-sharing percentages of various actors benefiting from sport hunting around Lake Mburo National Park (Fig. 1) and Kabwoya and Kaiso-Tonya Game Management Area (Fig. 2; UWA, 2012).

\begin{tabular}{|c|c|c|c|c|}
\hline \multirow[b]{2}{*}{ Actor } & \multicolumn{4}{|c|}{$\%$ revenue sharing } \\
\hline & 2001 & 2003 & 2008 & 2012 \\
\hline \multicolumn{5}{|l|}{ Lake Mburo National Park } \\
\hline Associations & 65 & 65 & 45 & 40 \\
\hline Government & 25 & 15 & 15 & 10 \\
\hline Landowner & 0 & 10 & 30 & 50 \\
\hline Institution & 5 & 5 & 5 & 0 \\
\hline Local government (sub-county) & 5 & 5 & 5 & 0 \\
\hline \multicolumn{5}{|c|}{ Kabwoya and Kaiso-Tonya Game Management Area } \\
\hline Government & & & 50 & \\
\hline Association & & & 20 & \\
\hline District local government & & & 15 & \\
\hline Kabwoya (sub-county) & & & 7.5 & \\
\hline Buseruka (sub-county) & & & 7.5 & \\
\hline
\end{tabular}

trade, research and education, and general extraction (WUR, 2000). Under sport hunting, individuals are licensed to hunt designated wildlife in or outside protected areas. Other legal documents that support the policy include the Uganda Wildlife Policy 1999, of which section 3.4.1 aims to create a facilitating environment for community and private sector participation in sustainable wildlife utilization, and the Uganda Wildlife Act (Cap 200 of 2000), section 29(1a) of which affirms wildlife use rights. These documents recognize that wildlife belongs to the government of Uganda, for its people. The rules for implementing sport hunting included revenue-sharing rules and other operational rules (e.g. quota allocation, hunting fees, and monitoring), including the 2001 professional hunting agreement signed by the government, the hunting company and the association.

According to the hunting agreement the benefit-sharing rules specified the following beneficiaries: the association would receive $65 \%$ of the fee, the government $25 \%$, institutions $5 \%$ and the sub-county $5 \%$ (Table 1 ). These were the same actors the government consulted to convince the Rurambiira residents to support sport hunting. In 2002 the government conducted an internal evaluation among the beneficiaries, and the results revealed that the policy provided substantial benefits to the communities $\left(\mathrm{R}_{3}\right)$. It was on this basis that the government opted to continue trialling sport hunting in Rurambiira parish. The communities soon became involved in the debates about sport hunting and demanded some rules be changed to include residents who owned land as direct beneficiaries (Table 1), reflecting incongruence between rules and resources. Although the residents owned the land where hunting was conducted, the 2001 revenue-sharing rules did not recognize them as beneficiaries. 
2003-2008 In this second period landowners started to challenge the policy arrangement, based on which the 2001 revenue-sharing rules were revised in 2003 . However, contrasting discourses and discontentment with the benefit-sharing rules remained, leading to the first battles over the benefits.

These battles resulted from (and were clearly reflected in) competing discourses. Whereas the government, institutions and hunting company perceived sport hunting as a means to derive benefits from wildlife for local residents, to change their attitudes towards wildlife and reduce human-wildlife conflict, for the residents sport hunting was a means to derive financial benefits but they also remained interested in reducing wildlife numbers, as wildlife competed with cattle for pasture, water and salt-licks, and destroyed crops.

The residents criticized sport hunting for perpetuating wildlife on their land. One interviewee $\left(\mathrm{R}_{32}\right)$ stated, '...we have seen an increase in invasions of wildlife on private land... sport hunting declared poaching illegal.' In response to this claim, a park official (R6) argued that the residents wrongly perceived that hunting would reduce wildlife on private land. He reaffirmed the policy's formal goals: '.. sport hunting was to reduce illegal hunting by the communities, while delivering benefits and to change their negative attitudes towards wildlife on private land.'

However, most landowners argued that 'they accommodate wildlife on their land and suffer wildlife damages' (R32). Consequently, the coalition of landowners and the association began to challenge openly the revenue-sharing rules and the government's hegemonic discourse, and advocated to be recognized as landowners. As they controlled the land, a key resource for policy implementation, they were able to overturn the 2001 revenue-sharing agreement in 2003 , to $65 \%$ for the association, $15 \%$ for the government, $10 \%$ for landowners, $5 \%$ for institutions and $5 \%$ for the subcounty (Table 1). Although the association's situation did not change, landowners gained $10 \%$ and together they became powerful actors in the arrangement, influencing debates and gaining more resources. Subsequently other new actors joined (residents of Nyakahiita and Rwakanombe parishes), who envied the benefits received by Rurambiira residents ( $\left.\mathrm{R}_{23}, \mathrm{R}_{33}, \mathrm{R}_{36}\right)$. The government permitted the same company to hunt in these parishes. Two new associations were founded, in Nyakahiita and Rwakanombe parishes, bringing the number of associations to three, all working with the same principles.

2008-2012 The third period was characterized by intense battles over the benefits, continued conflict between the government and the communities, further changes in the revenue-sharing rules and some incongruence between rules and resources.
In 2008 the government commissioned Enviro Consultancy League to evaluate the impacts of sport hunting in the three parishes. The outcomes were allegedly positive in terms of community development projects financed through hunting revenue. The consultant recommended the policy be extended to other areas, including Kabwoya (Muhimbura \& Namara, 2009). The post-evaluation period was characterized by negotiations leading to changes in the 2003 revenue-sharing rules in 2008 . The associations lost a significant percentage of revenue to landowners, while the percentages allocated to other actors remained as before (Table 1). However, landowners remained dissatisfied with the rules for benefit sharing because they received only $30 \%$ of the total revenue. They demanded to be granted at least $90 \%$ of the revenue to sustain meaningful livelihoods (R35).

Meanwhile it was claimed that some community members who resided in the capital, Kampala (hereafter the Kampala group), tried to hijack the sport hunting benefits in 2010. The elite Kampala group comprised larger landowners. They held several meetings in Kampala and invited some village residents to attend. Their intention was to 'improve community involvement in sport hunting, deliver more benefits to landowners, and to convince the government to fence the park to settle human-wildlife conflicts' $\left(\mathrm{R}_{31}, \mathrm{R} 45\right)$. The group founded a new association, the Lake Mburo Landowners Wildlife Association, which granted them absolute power over the benefits $\left(\mathrm{R}_{31}\right)$. However, some landowners, the old associations and some village opinion leaders opposed the group for not being initiated by the residents, not being accountable, and their views not necessarily representing the wider community. With the support of the Conservation Area Manager of Lake Mburo, the opposition to the group organized a joint meeting with the residents of the three parishes $\left(\mathrm{R}_{31}\right)$, where it was agreed to merge the old associations $\left(\mathrm{R}_{3} 6\right)$. Consequently, a new association, the Nshaara Wildlife Association, was founded, covering four sub-counties (Fig. 1), and taking over the management of the sport hunting benefits $\left(R_{31}\right)$. As a result the opposition managed to end the capturing of hunting benefits by the elite and abandon the Kampala association. However, although the communities gained more benefits they still demanded that the government fence the park to mitigate human-wildlife conflict.

2012-present The fourth period marked the settlement of the battles over the benefits in favour of landowners, and the emergence of winners and losers. Institutions and the sub-counties were excluded from the arrangement.

Following the continued implementation of sport hunting, the battles over the benefits intensified in 2012. The coalition of landowners and the association succeeded in influencing debates, and the revenue-sharing rule was 
amended so that landowners received 50\%, the association $40 \%$, and the government $10 \%$ (Table 1). At this point the government (the chief architect of the policy) and the association lost ground to the landowners. Landowners became winners, while the institutions and the sub-counties were no longer part of the benefit-sharing scheme. 'The current revenue-sharing rule gives landowners and the associations more power and opportunity to influence policy debates. However, smaller landholders complain that it only favours large landowners' (R21). Large landowners own large herds of livestock and receive $50 \%$ of the revenue, whereas small landowners are disadvantaged. One interviewee summarized the situation thus: "The problem is that some of us own smaller plots of land...the animals may have spent the night in my land...by morning they have crossed over to another person's land. When the sport hunters come, they find the animals in the other person's land (because his land is large), he is the only one that is paid and not me, yet I have also suffered losses' ( $\mathrm{R}_{32}$ ). In conclusion, although the current rules favour the communities in terms of giving them control over more benefits, their attitudes towards wildlife have not changed as a result. The association and landowners are still unsatisfied with the benefits, claiming they continue to suffer from damage caused by wildlife. Only the larger landowners, most of whom reside in Kampala, support hunting, because the size of their land favours hunting, and thus they receive more revenue.

\section{Kabwoya and Kaiso-Tonya Game Management Area}

Contrary to the situation at Lake Mburo, the sport hunting policy arrangement at Kabwoya has been relatively constant over time. Government agencies have remained in control of major resources. Although the communities show signs of discontentment, they do not own land where hunting is conducted, and therefore they are unable to change the arrangement.

Following an evaluation of the situation around Lake Mburo in 2008 (Muhimbura \& Namara, 2009), the government decided to extend sport hunting to Kabwoya. The policy goals were the same as in Lake Mburo: to reduce human-wildlife conflict and illegal hunting by providing benefits to the communities. Previously Kabwoya had experienced uncontrolled (subsistence) hunting, and encroachment of protected areas by the (pastoral) communities (R49). To derive income from wildlife, the government granted the company Lake Albert Safaris a hunting licence in 2008, and subsequent benefits were to be shared (R49). The licence was based on a $4 \%$ quota of the available population per species (R49, R52). However, official national rules in Uganda grant a $2 \%$ hunting quota of the population per species, reflecting inconsistencies between rules on paper and in practice.
To encourage participation by local actors in the Kabwoya arrangement, the government and the hunting company incorporated the Hoima District Local Government, Kabwoya and Buseruka sub-counties and the local communities (R52). Although the residents of Kabwoya supported sport hunting, the residents of Buseruka opposed it initially, arguing that the government wanted to grab land and would eventually restrict subsistence hunting (R49, R50). Following sensitization and persuasion by the government, the residents of Buseruka supported the policy $\left(\mathrm{R}_{51}, \mathrm{R}_{52}\right)$. The revenue-sharing rules were drafted, with the following beneficiaries: government (50\%), district (15\%), association (20\%), and Buseruka and Kabwoya sub-counties (7.5\% each; Table 1$)$. The government justified its 50\% share by arguing that it introduced sport hunting, that sport hunting was conducted within a government-owned game reserve, and that it needed to raise money to finance conservation and reduce poaching. One respondent $\left(\mathrm{R}_{51}\right)$ noted, 'the government is the most important partner. . their rangers ensure that encroachers are kept away from the reserves.'

To manage the $20 \%$ community benefits the Kabwoya and Kaiso-Tonya Community Wildlife Association was founded in 2009. Association membership included residents of Kabwoya, Buseruka and Kyangwali sub-counties (R51). Kyangwali sub-county joined the arrangement later, and to date benefits only from the association's $20 \% \mathrm{rev}-$ enue. The association is a registered community-based organization to manage hunting benefits and is supervised by the district $\left(\mathrm{R}_{55}, \mathrm{R}_{56}\right)$.

Because of the involvement of various actors who do not own land but who receive wildlife benefits, some residents have shown a positive attitude towards conservation (R49). Interviews with some association members indicated that they supported the idea that unrestricted use of environmental resources can lead to their decline. They believed that the government should grant residents only limited access to wildlife resources to safeguard resource sustainably ( $\left.\mathrm{R}_{56}\right)$. One interviewee $\left(\mathrm{R}_{51}\right)$ summarized the situation thus: 'We want to preserve the environment, for the good of the people; if you allow people to move freely here, it's a matter of months, it will go away.' Consequently, the association executives encourage former poachers to register as reformers (without prosecution), so they can receive meat from sport hunting as an additional benefit to the $20 \% \mathrm{rev}-$ enue $\left(\mathrm{R}_{57}\right)$. One respondent $\left(\mathrm{R}_{56}\right)$ noted, '... some meat is taken to the association leaders to be distributed among the members.' This is supposed to discourage poaching and other illegal activities. Some residents admitted they inform government rangers when wild animals stray into their communities, and rangers then drive them back into the reserves ( $\mathrm{R}_{56}$, $\mathrm{R}_{57}$ ). Under the 2013 association constitution, any member found poaching is arrested and prosecuted (R56). Consequently, poaching has been reduced at 
Kabwoya. One respondent (R55) noted, ' . . the communities used to kill the animals because they didn't know their importance, but the association involved the community, which made them feel important. . poaching stopped.'

Although this reflects a high level of congruence between actors, discourses and rules, some community members claimed that sometimes the government and hunting company hoarded the meat in their camps and did not share it with the communities $\left(\mathrm{R}_{50}\right)$. One respondent $\left(\mathrm{R}_{54}\right)$ suggested they '...bring the meat to the community and it is the executive to share it. . . the community will love the animals,' revealing another 'battle over the benefits'.

Whereas some community members agreed that sport hunting had partially achieved its goals of delivering benefits and reducing poaching, other members of the association criticized the arrangement. They accused the government of not inviting them to most meetings, especially when determining hunting rules, fees and quotas, and monitoring hunting ( $\left.\mathrm{R}_{51}, \mathrm{R}_{56}\right)$. One interviewee $\left(\mathrm{R}_{51}\right)$ lamented, '...we are never informed, yet we are part and parcel.' Similarly, association members expressed dissatisfaction with the fact that the hunting companies never revealed how many animals were hunted, or how much the association should expect at the end of the hunting season. 'They never tell us... they just give us the money by cheque' $\left(\mathrm{R}_{51}\right)$. Although the policy arrangement has proven relatively stable, with some notable positive changes in communities' attitudes towards wildlife, the Kabwoya arrangement is still characterized by mistrust and a lack of accountability and transparency. Mistrust in the arrangement reinforces passive community involvement, which undermines the principal aim of involving local residents. The current revenue-sharing rules reinforce the government's control over conservation, with the communities receiving benefits as determined by the government and its allies.

In conclusion, because the government dominated the Kabwoya arrangement it has remained the same over time. Although the communities showed willingness to support conservation and are deriving more benefits, they do not own land, and lack adequate financial resources and experience to negotiate or cause a change in the revenuesharing scheme, as at Lake Mburo.

\section{Discussion}

We used the policy arrangement approach (Arts et al., 2006) and the concept of congruence (Arts \& Goverde, 2006) to analyse the development of sport hunting policy in Uganda, with a focus on Lake Mburo and Kabwoya. The Lake Mburo policy arrangement evolved in four clear phases, illustrating incongruences among the dimensions of the policy arrangement approach. Land ownership emerged as a crucial factor for changes in benefit-sharing rules. However, although landowners received hunting benefits, their inclusion has not necessarily increased their support for conservation. Compared to Lake Mburo the Kabwoya arrangement was more stable over time, as the government remained the main landowner, could set and maintain the rules, and received $50 \%$ of the revenue. More generally, both arrangements started with small constellations of actors but developed as complex and messy arenas where debates were not focused on the formal aims of the policy arrangement (reducing poaching and changing community attitudes towards wildlife) but on battles over the benefits.

Discourses have influenced the arrangements in various ways. We found that the arrangements were characterized by two conflicting local discourses. The government's official discourse of changing communities' attitudes towards wildlife through benefits was challenged by a competing community discourse that considered wildlife to be a nuisance. Although the Lake Mburo communities received more money over time, they continually advocated fencing of the park to reduce human-wildlife conflict.

Human-wildlife conflict prevails in two ways: one where animals are regarded as pests (e.g. through the destruction of crops; Ochieng, 2011), and another where people poach wildlife (Duffy, 2000). The government implements the sport hunting policy to reduce poaching, whereas the communities interpret the formal goal of reducing human-wildlife conflict as reducing wildlife on private land and thus reducing its impact on livestock and farms. Consequently, the discursive incongruence remains unresolved and the communities still perceive benefits to be more important than wildlife. Solving human-wildlife conflict will not therefore automatically lead to communities protecting wildlife on private land. A related lesson learnt here is that human-wildlife conflict reflects conflict over land use, and therefore wildlife protection remains a daunting challenge for governments amidst changing land-use practices as the human population increases (Emerton, 1999).

Although the government's discourse links to the broader international discourse of promoting conservation through market-based approaches (McAfee, 1999; Fletcher, 2010), in Uganda this discourse remains implicit. The government expects to achieve its conservation goals after the communities have appreciated hunting benefits, stopped poaching and begun to protect wildlife on their farms. Whether this will be achieved remains uncertain. Another discourse, on concerns about the ethics of sport hunting and animal welfare and rights (Loveridge et al., 2006; Fischer et al., 2013), which is gaining increasing attention globally, has not influenced debates in Uganda.

Our analysis of the reintroduction of sport hunting in Uganda has four general findings. Firstly, we have shed light on the role of government in market-based conservation approaches. Across Africa sport hunting is practised and 
controlled by public, private and communal actors (Lindsey et al., 2007). Although this signals a declining role of state actors, the uncontrolled influence of non-state actors could result in unsustainable practices. To prevent this, governments should guide the implementation of such market-based approaches (Büscher et al., 2012); for example, by mobilizing resources and setting legal frameworks.

Secondly, we have raised questions about the durability and feasibility of implementing two different tourism models to raise funds for conservation, namely traditional tourism, based on tourists' love for and admiration of wildlife, and sport hunting. In Lake Mburo, traditional tourism is implemented within the National Park, and sport hunting is organized outside the park, whereas in Kabwoya both traditional tourism and sport hunting exist in the same landscape. Although this coexistence may appear to be viable in the short term, the combination seems impossible in the longer term, as traditional tourists may start avoiding areas where conservation-based tourism is combined with sport hunting when they realize that the same animal they admired within a protected area may be shot to make a profit once it crosses the protected area boundary.

Thirdly, market-based solutions are widely implemented across Africa to deliver conservation benefits (Booth, 2010; Nelson et al., 2013). However, implementation of sport hunting in Uganda led to mixed reactions from the communities. This finding shows that market-based solutions do not always bring about community involvement in conservation (Ahebwa et al., 2012a; van der Duim et al., 2015).

Fourthly, we have contributed to the literature on the role of tourism revenue-sharing in conservation and development (Archabald \& Naughton-Treves, 2001; Ahebwa et al., 2012a). The ongoing debate about big vs small landowners around Lake Mburo demonstrates the prevailing resource inequality among communities. The government's policy is to buy landowners' acceptance of wildlife on private land; however, the big landowners are more influential in the arrangement, and therefore most are able to supplement their income from livestock with hunting revenue, whereas the ability of small landowners to do so is limited. Similar results were recorded in the Maasai Mara, where elites with more land and livestock have greater opportunities to receive tourism revenues (Thompson et al., 2009), whereas smaller landowners do not usually receive substantial direct compensation for wildlife damages. Although tourism revenue-sharing is often considered to be a panacea for conservation challenges in Africa (Archabald \& Naughton-Treves, 2001), we found that most communities in both arrangements in Uganda considered livestock to be more important than wildlife. Around Lake Mburo the communities consistently called for the government to fence the park, even after they had received revenue from hunting. Our results also indicate that if benefits cease, animosity towards wildlife may be renewed. Regarding a similar case in Kenya, Anyango-Van Zwieten et al. (2015) argued that sustainability of the benefits is a necessary precondition to guarantee the success of incentive-based conservation approaches and avoid renewed animosity towards wildlife. Although market-based arrangements are widely supported and implemented, the basic assumption on which they are based may not hold. We therefore argue for a careful analysis of the complex and messy social, cultural and political contexts in which tourism revenuesharing is implemented.

\section{Acknowledgements}

We thank the Uganda Wildlife Authority and the Uganda National Council for Science and Technology for reviewing and approving this research project; the management and staff at Lake Mburo and Kabwoya; the district local leaders, conservation NGOs, tourism associations, hunting companies and local communities who participated in interviews; and the two anonymous reviewers for their tremendously helpful comments.

\section{Author contributions}

$\mathrm{AO}, \mathrm{IJVH}$ and RVDD conceived and drafted the research instruments, analysed the data and wrote the article. AO collected the data. IJVH and RVDD edited and reviewed analytical procedures and ensured adherence to sound research practices.

\section{References}

Ahebwa, W.M., van der Duim, R. \& Sandbrook, C.G. (2012a) Tourism revenue sharing policy at Bwindi Impenetrable National Park, Uganda: a policy arrangements approach. Journal of Sustainable Tourism, 20, 377-394.

Ahebwa, W.M., van der Duim, R. \& Sandbrook, C.G. (2012b) Private-community partnerships: investigating a new approach to conservation and development in Uganda. Conservation and Society, 10, 305-317.

Anyango-Van Zwieten, N., van der Duim, R. \& Visseren-Hamakers, I.J. (2015) Compensating for livestock killed by lions: payment for environmental services as a policy arrangement. Environmental Conservation, 42, 363-372.

Archabald, K. \& Naughton-Treves, L. (2001) Tourism revenue-sharing around national parks in Western Uganda: early efforts to identify and reward local communities. Environmental Conservation, 28, 135-149.

Arts, B. \& Buizer, M. (2009) Forests, discourses, institutions: a discursive-institutional analysis of global forest governance. Forest Policy and Economics, 11, 340-347.

Arts, B. \& Goverde, H. (2006) The governance capacity of (new) policy arrangements: a reflexive approach. In Institutional Dynamics 
in Environmental Governance (eds B. Arts \& P. Leroy), pp. 69-92. Springer, Dordrecht, The Netherlands.

Arts, B., Leroy, P. \& van Tatenhove, J. (2006) Political modernisation and policy arrangements: a framework for understanding environmental policy change. Public Organization Review, 6, 93-106.

Arts, B. \& van Tatenhove, J. (2004) Policy and power: a conceptual framework between the 'old' and 'new' policy idioms. Policy Sciences, 37, 339-356.

Ayorekire, J., Ahebwa, M.W. \& Ochieng, A. (2011) Managing conservation and development on private land: an assessment of sport hunting around Lake Mburo National Park, Uganda. In New Alliances for Tourism, Conservation and Development in Eastern and Southern Africa (eds R. van der Duim, D. Meyer, J. Saarinen \& K. Zellmer), pp. 185-201. Eburon, Delft, The Netherlands.

Bоотн, V.R. (2010) The contribution of hunting tourism: how significant is this to national economies? In Contribution of Wildife to National Economies. Joint publication of FAO and CIC, Budapest, Hungary.

Büscher, B., Sullivan, S., Neves, K., Igoe, J. \& Brockington, D. (2012) Towards a synthesized critique of neoliberal biodiversity conservation. Capitalism Nature Socialism, 23, 4-30.

Decrop, A. (2004) Trustworthiness in qualitative tourism research. In Qualitative Research in Tourism: Ontologies, Epistemologies and Methodologies (eds J. Phillimore \& L. Goodson), pp. 156-169. Routledge, London, UK.

Duffy, R. (2000) Killing for Conservation: Wildlife Policy in Zimbabwe. James Currey, Oxford, UK.

Emerton, L. (1999) Balancing the Opportunity Costs Of Wildlife Conservation For Communities Around Lake Mburo National Park, Uganda. Evaluating Eden Series, Discussion Paper No. 5. International Institute for Environment and Development, London, UK.

Fereday, J. \& Muir-Cochrane, E. (2006) Demonstrating rigor using thematic analysis: a hybrid approach of inductive and deductive coding and theme development. International Journal of Qualitative Methods, 5, 80-92.

Fischer, A., Kereži, V., Arroyo, B., Mateos-Delibes, M., Tadie, D., LowAssa, A. et al. (2013) (De)legitimising hunting-discourses over the morality of hunting in Europe and eastern Africa. Land Use Policy, 32, 261-270.

Fletcher, R. (2010) Neoliberal environmentality: towards a poststructuralist political ecology of the conservation debate. Conservation and Society, 8, 171-181.

Giddens, A. (1984) The Constitution of Society: Outline of the Theory of Structuration. University of California Press, Oakland, USA.

Hajer, M. (1995) The Politics of Environmental Discourse: Ecological Modernization and the Policy Process. Oxford University Press, Oxford, UK.

Hulme, D. \& Murphree, M. (eds) (2001) African Wildlife and Livelihoods: The Promise and Performance of Community Conservation. James Currey, Oxford, UK.

Hutton, J.M. \& Leader-Williams, N. (2003) Sustainable use and incentive-driven conservation: realigning human and conservation interests. Oryx, 37, 215-226.

Kuindersma, W., Arts, B. \& van der Zouwen, M.W. (2012) Power faces in regional governance. Journal of Political Power, 5 , 411-429.

Kumar, R. (2012) Research Methodology: A Step-by-Step Guide for Beginners. Sage Publications Ltd., London, UK.

Lamers, M., van der Duim, R., van Wijk, J., Nthiga, R. \& Visseren-Hamakers, I.J. (2014) Governing conservation tourism partnerships in Kenya. Annals of Tourism Research, 48, 250-265.

Lewis, D.M. \& Alpert, P. (1997) Trophy hunting and wildlife conservation in Zambia. Conservation Biology, 11, 59-68.

Lindsey, P.A., Frank, L.G., Alexander, R., Mathieson, A. \& RomaÑACH, S.S. (2007) Trophy hunting and conservation in Africa: problems and one potential solution. Conservation Biology, 21, 880-883.

Loveridge, A.J., Reynolds, J.C. \& Milner-Gulland, E. (2006) Does sport hunting benefit conservation? Key Topics in Conservation Biology (eds D. Macdonald \& K. Service), pp. 222-238. Blackwell Publishing, Oxford, UK.

McAfee, K. (1999) Selling nature to save it? Biodiversity and green developmentalism. Environment and Planning D: Society and Space, 17, 133-154.

Munimbura, A. \& Namara, A. (2009) The Pilot Sport Hunting Program in the Ranches Surrounding Lake Mburo National Park. Project evaluation report, draft 2.

Nelson, F., Lindsey, P. \& B Alme, G. (2013) Trophy hunting and lion conservation: a question of governance? Oryx, 47, 501-509.

OCHIENG, A. (2011) Linking tourism, conservation and livelihoods: an analysis of sport hunting around Lake Mburo National Park, Uganda. MSc thesis. Wageningen University, Wageningen, The Netherlands.

Ochieng, A., Ahebwa, W.M. \& Visseren-Hamakers, I.J. (2015) Hunting for conservation? The re-introduction of sport hunting in Uganda examined. In Institutional Arrangements for Conservation, Development and Tourism in Eastern and Southern Africa (eds R. van der Duim, M. Lamers \& J. van Wijk), pp. 139-155. Springer, Dordrecht, The Netherlands.

Rhodes, R.A. (1997) Understanding Governance: Policy Networks, Governance, Reflexivity and Accountability. Open University Press, Buckingham, UK.

Thompson, D.M., Serneels, S., Ole Kaelo, D. \& Chenevix Trench, P. (2009) Maasai Mara-land privatization and wildlife decline: can conservation pay its way? In Staying Maasai? Livelihoods, Conservation and Development in East African Rangelands (eds K. Homewood, P. Kristjanson \& P. Chenevix Trench), pp. 77-114. Springer, New York, USA.

UWA (Uganda Wildlife Authority) (2001) Professional Hunting Agreement in the Former Ankole Ranching Scheme Between Uganda Wildlife Authority and Rurambiira Wildlife Association and Game Trails (U) Limited. UWA, Kampala, Uganda.

UWA (Uganda Wildlife Authority) (2012) Sport Hunting Companies in Uganda. Uganda Wildlife Authority, Kampala, Uganda.

UWP (Uganda Wildife Policy) (2004) The Uganda Wildlife Policy. Ministry of Tourism, Trade and Industry, Kampala, Uganda.

van der Duim, R., Lamers, M. \& van Wijk, J. (eds) (2015) Institutional Arrangements for Conservation, Development and Tourism in Eastern and Southern Africa: A Dynamic Perspective. Springer, Dordrecht, The Netherlands.

VAN DER ZOUWEN, M. (2006) Nature policy between trends and tradition: dynamics in nature policy arrangements in the Yorkshire Dales, Donana and the Veluwe. PhD thesis. Radboud University, Nijmegen, The Netherlands.

Van Gossum, P., Arts, B., De Wulf, R. \& Verheyen, K. (2011) An institutional evaluation of sustainable forest management in Flanders. Land Use Policy, 28, 110-123.

Wiering, M. \& ARTs, B. (2006) Discursive shifts in Dutch river management: 'deep' institutional change or adaptation strategy? Hydrobiologia, 565, 327-338. 
WUR (Wildlife User Rights) (2000) Wildlife User Rights. Uganda Wildlife Authority, Kampala, Uganda.

YASUDA, A. (2012) Is sport hunting a breakthrough wildlife conservation strategy for Africa? A case study of northern Cameroon. Field Actions Science Reports, 6, https://factsreports. revues.org/1362.

Yin, R. (2003) Case Study Research: Design and Methods. 3rd edition. Sage Publications, Thousand Oaks, USA.

\section{Biographical sketches}

Amos Ochieng's research focuses on the use of sport hunting to promote tourism, conservation and development. INGRID J. VISSERENHAMAKERS' research is centred on international biodiversity governance, with a focus on integrative environmental governance. RENÉ VAN DER DUim's research focuses on the relation between tourism, conservation and development, especially in sub-Saharan Africa. 